\title{
LEXICAL ACCESS IN CATALAN SIGNED LANGUAGE (LSC) PRODUCTION
}

\author{
Cristina Baus $^{1,2}$, Eva Gutiérrez-Sigut ${ }^{1,2}$, Josep Quer $^{3}, \&$ Manuel Carreiras ${ }^{1,2}$ \\ ${ }^{1}$ Facultad de Psicología. Universidad de La Laguna, Tenerife, Spain \\ ${ }^{2}$ Instituto de Tecnologías Biomédicas. Universidad de La Laguna, Tenerife, Spain \\ ${ }^{3}$ Universiteit van Amsterdam, The Netherlands.
}

Running head: lexical access in signed language production.

Word count: 4137

Address correspondence to:

Cristina Baus

Departamento de Psicología Cognitiva

Facultad de Psicología

Universidad de La Laguna

38205- Tenerife, SPAIN.

email: cbausma@ull.es

url : www.neurocog.ull.es

Fax: +34 922317461 


\begin{abstract}
This paper investigates whether the semantic and phonological levels are specific to spoken languages or universal across modalities. We examined semantic and phonological effects during Catalan Signed Language (LSC: Llengua de Signes Catalana) production using an adaptation of the picture-word interference task: Native and non-native signers were asked to sign picture names while ignoring signs produced in the background. The results showed semantic interference effects for semantically related distractor signs and phonological facilitation effects when target signs and distractor signs shared either Handshape or Movement but phonological interference effects when target and distractor shared Location. The results suggest that the general distinction between semantic and phonological levels seems to hold across modalities. However, differences in sign language and spoken production become evident in the mechanisms underlying phonological encoding, shown by the different role that Location, Handshape and Movement play during phonological encoding in sign language.
\end{abstract}


Both spoken and signed languages communicate ideas. However, it is yet unknown whether similar processing mechanisms underlie the production of words and signs. Most models of speech production (e.g. Caramazza, 1997; Dell \& O’Seaghdha, 1992; Levelt, Roelofs, \& Meyer, 1999) assume lexical access to be a two-step process, that is, they differentiate between semantic activation/selection and phonological encoding.

All of these models assume that during lexical selection the target representation has to be selected from a cohort of semantically related representations. The higher the activation levels of potential competitors, the more difficult (and time consuming) this selection process will be. Discrete-serial models (e.g., Levelt et al., 1999) postulate that only the selected semantic representation will subsequently activate its word-form. Cascading models of lexical access (e.g., Caramazza, 1997; Dell \& O'Seaghdha, 1992) assume that all activated semantic representations will activate their word-forms to a certain degree. In the remainder of the paper we will focus on the distinction between semantic and phonological processing without differentiating between serial-discrete and cascading models of speech production.

Evidence supporting this distinction between semantics and phonology comes from speech error analysis (e.g., Garrett, 1980), performance of patients with braindamage (e.g., Badecker, Miozzo, \& Zanuttini, 1995) and reaction-time data from picture-naming tasks (e.g., Schriefers, Meyer, \& Levelt, 1990). Some sign language data suggest that these two levels may also apply to sign languages (Corina, 2000; Hohenberger, Happ, \& Leuninger, 2002; Newkirk, Klima, Pedersen, \& Bellugi, 1980; Thompson, Emmorey, \& Gollan, 2005). In particular, Thompson et al. (2005) showed that deaf participants in a tip-of-the-finger (TOF) state (which parallels TOT in spoken languages) had partial access to phonological information, Handshape, Orientation, 
Location and Movement, while no access to the whole sign, suggesting that there is a distinction between semantics and phonology in sign language. In contrast, however, the semantic phonology theory (Stokoe, 1991; Amstrong, Stokoe, \& Wilcox, 1995) and approaches to sign languages as essentially iconic communication systems (e.g. Cuxac, 2000) propose that signs are units based on semantically transparent representations and that no distinction between the meaning of the sign and its phonological parameters should be made.

Empirical evidence regarding sign language production, a research area still in its infancy, is very scarce and has been obtained mainly through sign production errors (Hohenberger et al., 2002), brain-damaged patients' signing performance (Newkirk et al., 1980) and only very recently from a TOF study (Thompson et al., 2005). However, the information obtained using these off-line tasks is limited and on-line methods are preferable to obtain more detailed information about production processes (see Meyer, 1992), allowing a better comparison between signed and spoken production. One of the most successful on-line paradigms in language production research is the picture-word interference task, in which participants name a picture while ignoring an auditory or visually presented distractor word (Rayner \& Posnansky, 1978). Picture-naming is slowed when the distractor is a semantically related word in comparison to when it is an unrelated word (Glaser \& Düngelhoff, 1984; Glaser \& Glaser, 1989; La Heij, 1988; Levelt et al., 1991; Lupker, 1979; Schriefers et al., 1990). In contrast, pictures are named faster when presented together with phonologically related words. Accordingly, semantic and phonological information can be assumed to involve different processing mechanisms. Here, we investigate whether the same pattern of results comes about in sign language production. If so, this would make a case against the semantic phonology 
theory and be in favour of similar mechanisms in spoken and signed language production.

From the very beginnings of linguistic analysis of sign languages, it was proposed that signs can be decomposed into three main phonological parameters (Stokoe, 1960): Handshape, Location of the sign in relation to the body, and Movement of the hands. According to the dominant view in current theorizing on sign linguistic structure, these parameters are meaningless by themselves and it is only through their combination that morphemes and word-signs are created (Emmorey, 2002). But this consideration is not accepted by all the linguistic models. For instance, Johnston (1989) and Johnston \& Schembri (1999) argue that, Location, Movement and Orientation (as well as non-manual features) are often individually meaningful in sign languages. For these authors, the phonological components of the sign should be analyzed as phonemes and morphemes at the same time, hence, they refer to these component aspects as 'phonomorphemes'. This implies that the minimal building blocks of signs are considered to be meaningful in most cases.

The main argument for the existence of phonological parameters in sign processing comes from the existence of minimal phonological pairs (signs that only differ in one of the three parameters). Results from different studies and paradigms have shown that Handshape, Location and Movement influence sign-recognition in different manners (e.g., Brentari, 2006; Carreiras, Gutiérrez-Sigut, Baquero, \& Corina, 2008; Corina \& Hildebrandt, 2002; Corina \& Knapp, 2006; Hildebrandt \& Corina, 2002). For instance, using a priming paradigm studying two of these three parameters, Location and Handshape, Carreiras et al. (2008) showed that targets preceded by signs sharing Location were responded to slower than when preceded by an unrelated sign, while they were responded to faster when preceded by signs sharing Handshape. Furthermore, 
signs sharing Location with many other signs were responded to slower than signs sharing Location with only a few. However, the opposite effect was found for Handshape. Thus, Location seems to cause interference, whereas Handshape seems to cause facilitation.

The question we address here is whether the three parameters (Handshape, Movement and Location) play the same or a different role during phonological encoding in sign production. Taking into account that Location and Handshape play different roles in sign comprehension, it is quite likely that they may also play different roles in sign production.

Finally, since previous work has demonstrated that age of exposure to language results in subtle but measurable differences in sign language processing (Carreiras et al., 2008; Corina \& Hildebrandt, 2002; Newport, 1990; Mayberry \& Fischer, 1989; Newman et al., 2002) age of sign language acquisition was included as a factor in the present study. This might be important, as research has demonstrated that late learners of sign languages may experience a "phonological bottleneck" that results in less efficient processing of form-based properties of signs. Mayberry \& Fischer (1989) found that early and late signers behaved differently in solving semantic and phonological details, respectively. While native signers made primarily semantic errors, non-native signers made primarily phonological errors. In the present experiment, we ask if this is a systematic difference, also reflected in picture signing. Considering the phonological bottleneck effect, we should expect the native group to outperform the non-native group in the phonological condition. In addition, we address whether this benefit of the native signers will be equal for all the phonological parameters. 


\section{METHOD}

\section{Participants}

Twenty-four deaf signers participated in this study (eleven women). All of them were deaf from birth and used Catalan Sign Language (LSC) as preferred means of communication. LSC is the official sign language used in Catalonia by around 7,000 deaf signers. Twelve participants were native signers (from deaf families) and had LSC as their first language (age range 18-51, mean age 30.3, S.D=7.6) and twelve were nonnative signers (from hearing families) (age range 18-44, mean age 26.4, $\mathrm{S} . \mathrm{D}=5.8$ ) who learned LSC at the mean age of 12 (age of exposure range 10-31 years) Participants were recruited from the two main Deaf Associations in Barcelona and were paid for their participation.

\section{Materials}

Thirty line-drawings of simple objects were selected from the Snodgrass \& Vanderwart picture database (1980) and similar databases. The picture of the object was superimposed on a video of a native deaf person signing (see Figure 1). With the aid of an expert native informant, for each picture, three video-signs (distractors) were selected: one phonologically related, one semantically related and one unrelated. In the phonological condition, the sign corresponding to the picture and the video-sign shared one of the three parameters: Handshape, Movement or Location (ten items per condition). Although the same pictures were used in the semantic, unrelated and phonological conditions, they were different for each of the phonological conditions. In the semantic condition, both signs were semantically related and did not share any of the three phonological parameters. In the unrelated condition, the two signs had no 
phonological or semantic relationship (see the Appendix for a complete list of materials).

All videos had a duration of approximately $500 \mathrm{~ms}$ (18 to 20 frames) and comprised both the video distractor and the picture, that is, the picture appeared simultaneously with the onset of distractor sequence and remained visible on the screen together with the last frame of the video distractor until participants responded. During the filming session, a native deaf signer was instructed to sign the distractor-sign in the context of a carrier phrase (Signed Language sign + the distractor-sign). For those signs with contact to the body, the beginning of the actual sign was the point in time when contact occurred, and for those signs with no contact to the body it was the point in time when the path movement started. The video sequences of the distractor-sign started two frames before the actual sign started and ended two frames after the sign finished (see Corina \& Hildebrandt, 2008 for a similar procedure).

--- Insert Figure 1 around here ---

\section{Procedure}

Each participant was tested individually. Participants were videotaped during the experimental session to score trials with errors. Stimulus presentation and reaction times were controlled by Psyscope software (Cohen et al. 1993).

Each trial involved the following events: (a) an instruction indicating that a new trial was about to start so the participants should press the response buttons with their hands and not raise them until they signed the picture that appeared later; (b) a fixation point (an asterisk) in the center of the screen for $500 \mathrm{~ms}$; (c) a blank interval of $300 \mathrm{~ms}$; (d) the video (including the picture) which lasted for $500 \mathrm{~ms}$ and when finished 
remained static in the background of the picture until the participant's response; (e) the next trial, which started $2000 \mathrm{~ms}$ after the participant's response. From the moment the picture target appeared on the screen, an external button box device registered the reaction time by stopping the clock when the participant lifted her hands off the button box to sign the picture target.

Each picture was presented three times, one for each condition (phonological, unrelated and semantic). Two pseudo-randomized lists of stimuli were created, considering the following criteria: (a) No picture was preceded by a phonologically or semantically related picture; (b) not more than two trials of the same distractor type followed in direct succession.

Before the experiment started, participants were shown a booklet with all the pictures of the experiment, to ensure they used the designated sign during the experiment. Afterwards, participants received ten practice trials to familiarize them with the task.

\section{RESULTS}

Videotaped recordings were checked for production of signs that differed from those previously designated (three pictures, one in the Handshape and two in the Movement condition, were excluded because more than $20 \%$ of the time the picture was not signed as intended by the experimenter). In addition, disfluent responses were excluded (similar to verbal disfluences in spoken languages, $7.7 \%$ of errors).

Furthermore, reaction times below $200 \mathrm{~ms}$. or above $1500 \mathrm{~ms}$. were excluded from the data analysis (7.1\%, of which $4.7 \%$ was below $200 \mathrm{~ms})$. One participant was excluded due to technical problems during the experimental phase. Due to the 
variability between subjects, median scores were used to analyse reaction times (Ratcliff, 1993).

A $3 \times 2$ analysis of variance (ANOVA) by participants $\left(\mathrm{F}_{1}\right)$ and by items $\left(\mathrm{F}_{2}\right)$ on signing latencies and accuracy was carried out, with type of distractor (semantic/phonological/unrelated) as within-participants and between-items factor and group (native/non-native) as between-participants and within-items.

Analyses of the error rates showed no significant differences (all $F$ 's $<1$ ).

Naming latencies (see Table 1) revealed a main effect of type of distractor $F_{1}(2$, $42)=8.67, p<.01 ; F_{2}(2,52)=3.02, p=.05$. No effect of group was found $F_{1}(1,21)=$ $1.62, p=.21 ; F_{2}(1,26)<1$. The interaction between type of distractor and group was not significant $F_{1}(2,42)=2.30, p=.11 ; F_{2}(2,52)<1$, showing that there were no differences in reaction times between natives and non-natives in any of the conditions (see Table1).

Analyses considering type of distractor revealed a semantic interference effect when compared with the unrelated condition $F_{1}(1,21)=9.05, p<.01 ; F_{2}(1,26)=4.25$, $p<.05$. Pictures in the semantic related condition were signed $19 \mathrm{~ms}$ slower than the same pictures in the unrelated condition. Signing latencies did not differ between the unrelated condition and the phonological condition containing all three types of phonological distractors $\left(F_{1}(1,21)=1.33, p=.26 ; F_{2}(1,26)<1\right)$. 
TABLE 1.

Mean reaction times $(R T)(S D$ in parenthesis) and percentage error rates (\%error).

\begin{tabular}{|c|c|c|c|c|}
\hline \multirow[t]{2}{*}{$\begin{array}{c}\text { TYPE OF } \\
\text { DISTRACTOR }\end{array}$} & \multicolumn{2}{|c|}{ NATIVES } & \multicolumn{2}{|c|}{ NON NATIVES } \\
\hline & $\mathrm{RT}(\mathrm{SD})$ & \%error & $\mathrm{RT}(\mathrm{SD})$ & \%error \\
\hline UNRELATED & 545 (219) & 8.3 & $506(174)$ & 8.5 \\
\hline $\begin{array}{l}\text { SEMANTICALLY RELATED } \\
\text { Effect (Related-Unrelated) }\end{array}$ & $\begin{array}{l}566(219) \\
21\end{array}$ & $\begin{array}{l}8.4 \\
0.1\end{array}$ & $\begin{array}{l}524(161) \\
18\end{array}$ & $\begin{array}{c}7.3 \\
-1.3\end{array}$ \\
\hline $\begin{array}{l}\text { PHONOLOGICALLY RELATED } \\
\text { Effect (Related - Unrelated) }\end{array}$ & $\begin{array}{l}537(212) \\
-\mathbf{8}\end{array}$ & $\begin{array}{r}6.7 \\
-1.6\end{array}$ & $\begin{array}{l}512(171) \\
6\end{array}$ & $\begin{array}{r}7.9 \\
-1.4\end{array}$ \\
\hline
\end{tabular}

Additional $3 \times 2 \times 2$ ANOVAs were carried out with type of phonological distractor (Handshape, Movement, and Location), relatedness (related/unrelated) and group (native/non native) as factors. The main effects of type of phonological distractor, relatedness and group were non significant (all $F^{\prime}$ s $<1$ ). Importantly, the relevant interaction between relatedness and type of phonological distractor was significant $F_{1}$ $(2,42)=9.53, p<.001 ; F_{2}(2,28)=7.26, p<.01$ indicating different effects for the phonological parameters. The interaction between relatedness, type of phonological distractor and group was non significant (both $F$ 's $<1$ ).

Planned comparisons based on the significant interaction between relatedness and type of phonological distractor were performed to assess the differential effects of Handshape, Movement and Location (see Table 2). Picture signing was $21 \mathrm{~ms}$ faster with Handshape-related distractors than with unrelated distractors yielding a significant facilitatory effect for Handshape $\left(F_{1}(1,21)=5.22, p<.05 ; F_{2}(1,16)=3.83, p=.06\right)$. Moreover, pictures sharing Movement with the distractor-sign were $18 \mathrm{~ms}$ faster than the same pictures with an unrelated distractor-sign, although analysis were only significant by participants $\left(F_{1}(1,21)=4.73, p=.05 ; F_{2}(1,14)=1.14, p=.30\right)$ 
The opposite effect was found for Location. Pictures were signed 34 ms slower when presented with Location-related distractors than with unrelated distractors $F_{1}(1$, $21)=16.94, p<.001 ; F_{2}(1,18)=3.75, p=.06$.

TABLE 2.

Mean reaction times (Standard Deviations in parenthesis) and percentage of error rates

\begin{tabular}{|c|c|c|c|}
\hline $\begin{array}{l}\text { TYPE OF } \\
\text { PHONOLOGICAL DISTRACTOR }\end{array}$ & & RT (SD) & \%error \\
\hline \multirow[t]{3}{*}{ HANDSHAPE } & Related & $519(194)$ & 4.2 \\
\hline & Unrelated & 539 (198) & 6.0 \\
\hline & Effect & -20 & -1.9 \\
\hline \multirow[t]{3}{*}{ MOVEMENT } & Related & $521(190)$ & 7.3 \\
\hline & Unrelated & $538(198)$ & 6.8 \\
\hline & Effect & -18 & 0.5 \\
\hline \multirow[t]{3}{*}{ LOCATION } & Related & $535(191)$ & 10.6 \\
\hline & Unrelated & 501 (194) & 9.6 \\
\hline & Effect & 34 & 0.9 \\
\hline
\end{tabular}

\section{DISCUSSION}

The results show that the distinction between semantics and phonology in speech production also seems to hold for sign production. Deaf participants signed pictures slower when presented with a semantically-related distractor than when presented with an unrelated distractor. In contrast, no overall differences were found between the phonological and the unrelated condition. However, when the parameters in the phonological condition were analysed separately, two opposite effects were observed. Participants signed pictures faster when presented with distractors that shared either Handshape or Movement, two phonological parameters, but slower when presented with distractors that shared Location. Results relative to group of participants did not show any significant differences between natives and non-natives in any of the conditions. This lack of differences between the groups of participants could be influenced by the fact that natives and non-natives were highly proficient in LSC and both used signed 
language as preferred mean of communication. Another possibility would be that the picture-sign paradigm was not sensitive enough to capture differences between natives and non-natives.

The different pattern of results found for semantics and phonology speak against the semantic phonology theory (Stokoe, 1991) or similar theories (Amstrong et al., 1995; Cuxac, 2000; Johnston, 1989; Johnston \& Schembri, 1999) which assume no distinction between semantics and the phonological parameters, as they consider signs to be essentially iconic.

The results from this experiment clearly mirror results from the oral domain indicating that lexical selection is language universal and not affected by the modality in which the language is produced. However, these results seem to suggest that speech and sign language production differ in phonological encoding processes during language production. While in spoken languages phonological distractors have, in most cases, resulted in a facilitatory effect, in signed language a null effect has been found when all parameters are considered together, as the different parameters produce opposite effects. While picture-signing was faster with Handshape and Movement distractors, it was slower with Location distractors, in comparison with the unrelated condition in all cases. These results provide new evidence for different roles of the three phonological parameters during processing.

Regarding the effect of each of the three phonological parameters separately, it is important to note that other studies have shown differences between Location and Handshape in acquisition, perception and neuropsychological domains. For example, Location is one of the earliest and most accurately acquired properties in sign language acquisition (Marentette \& Mayberry, 2000; Meier, 2000) and one of the most resistant to substitution or change under conditions of language impairment (Corina, 2000), 
whereas Handshape errors are the most commonly-reported errors in aphasic signing patients (Corina, 2000). In perception, using the lexical decision task and/or priming paradigms, the most common finding for Location has been inhibition, while facilitation has been found for Handshape (Carreiras et al., 2008; Corina \& Hildebrandt, 2002).

These differential effects for Location and Handshape obtained both in sign perception (Carreiras et al., 2008) and now in production may be reflecting representational or processing differences. It could be argued that the inhibitory effect for Location can be explained by its being the only parameter semantically driven, as proposed by Stokoe's theory, or at least, that it is located at a different level from the phonological level where Handshape and Movement are. But this assumption is hard to accept, because if we put aside some so-called motivated sign families (i.e. signs referring to feelings, that are articulated on the heart/chest region, signs of intellectual activity articulated on the forehead, or signs denoting body parts, for instance), Location in signing space is highly arbitrary. Location regions are extremely dense in terms of the lexical entries that are specified for them. Further research should investigate why Location effects are not in line with predictions for phonological encoding processes and should attempt to determine the temporal course of the three phonological parameters during sign production.

The effects observed for Movement seem to reinforce the argument that differential effects may be linked to a sequential processing of the different parameters. Movement also showed a facilitatory pattern, and studies of sign perception (Emmorey \& Corina, 1990) and production (Thompson et al., 2005) have found that Movement is the last parameter to be accessed. However, in a recent picture-sign production experiment, Corina and Knapp (2006) did not find phonological effects in sign production when manipulating one parameter at a time, although this could have been 
caused by the fact that they had very few observations per cell. Interestingly, however, Corina and Knapp (2006) and Baus and Carreiras (submitted) found phonological facilitation when the distractor and target shared Movement and Location. As several sign language theories have considered Movement and Location as the skeletal structure from which a "syllabic unit" is formed in signing (e.g., Brentari, 1998; Perlmutter, 1992; Wilbur, 1993), this may be reflected in the syllabic effects also reported in spoken production (Cholin, Schiller, \& Levelt, 2004; Carreiras \& Perea, 2004). Perlmutter (1992) explained this syllabic unit as analogous to the CVC (Location-MovementLocation) syllable in oral languages, where the Movement would correspond to the peak of sonority and hence would be analogous to the vowel, while Location would be analogous to the consonant in oral languages.

Despite all these models agreeing on the sonority distinction between Movement and Location, what is not totally clear is the role of the Handshape in this range of sonority, where Movement and Location would occupy the extremes. For some models (Corina \& Sandler, 1993; Chinchor, 1978; Wilbur, 1993), the Handshape parameter, when it implies an internal change, is considered to be more sonorous than Location. Given the fact that some of the signs in the Handshape condition used in our experiment had internal movement, the facilitatory effect found in this condition could be explained partially by the greater sonority of these Handshape signs which have internal movement.

The fact that one phonological parameter (Location) produced an opposite effect to the usual facilitatory phonological effects found in the picture word interference paradigm in spoken production indicates some degree of sequentiality in sign phonology processing. To our knowledge, no inhibitory phonological effects have been found with the "standard" picture word interference paradigm (i.e. single picture 
naming, one word utterance) in spoken production ${ }^{1}$. Nonetheless, it is interesting to note that in one speech production study (Wheeldon, 2003), picture naming was inhibited by the prior production of a word sharing the onset segments (e.g. bloed-bloem) while it was facilitated when they shared the rhyme segments (e.g kurk-jurk) (see however, Meyer \& Schriefers, 1991 and Sullivan \& Riffel, 1999). In addition, using a syllable recitation task, Sevald and Dell (1994) observed that performance was inhibited when syllable sets shared initial phonemes, but facilitated when they shared final phonemes. Sevald and Dell (1994) suggested that a phoneme competition takes place during a leftto-right assignment of phonemes to a syllable frame. They argued that the increased activation due to shared initial phonemes leads to a miscuing of the possible syllable final phonemes, which then compete for selection. In contrast, for syllables sharing final phonemes, nothing follows the shared phonemes, to be miscued (see also O'Seaghdha \& Marin, 2000, for a revised version of the sequential phonological competition, including parallel processing, proposed by Sevald \& Dell, 1994). Nonetheless, to account for the present pattern of data, this model would have to assume that Location is miscuing Handshape and Movement, which is beyond the scope of the model. Thus, no current model of word form encoding provides an account of the pattern of results observed with sign language. However, according to some sign language phonology models (e.g., Brentari, 1998, Perlmutter, 1992, Wilbur, 1993) the initial Location constitutes the onset of the syllable, while Movement is the nucleus, thus, the predictions from the Sevald \& Dell (1994) proposal could apply to our data. If, in addition, an explanation for the Handshape and its position in the syllable structure was provided by the same sign phonology models, this would complete the puzzle of the differential results obtained for the three phonological parameters. However, further

\footnotetext{
${ }^{1}$ However, phonological interference has been reported, in picture naming studies (Jescheniak, Schriefers, \& Hantsch, 2003; Meyer, 1996), when the target word was at the end of complex utterances (e.g. the big green house).
} 
investigation of static handshapes is necessary, to verify whether the facilitatory effect of this parameter is general or applicable only to those with internal movement. The clue probably lies in the fact that the same Handshape is linked in a one-to-many fashion to the elements that structure the syllable.

In sum, although we know that signed and spoken languages are different in many aspects, this study suggests that when the aim is to communicate ideas, both involve two different levels, so that the separation of semantics and phonology seems to be not modality independent, but a language universal processing pattern. Semantic effects seem to be inhibitory across modalities and hence, during lexical selection the same mechanisms could apply to sign and spoken languages. In contrast, differences in modality seem to be in the mechanisms underlying the phonological encoding. In the case of sign language, the phonological effects found for Handshape, Movement and Location are influenced by the status of each of these parameters in the sign. 


\section{ACKNOWLEDGEMENTS}

This research has been partially supported by Grants SEJ2004-07680-C0202/PSIC and SEJ2006-09238/PSIC from the Spanish Government. We thank all the deaf volunteers and the deaf associations CERECUSOR and CASAL DE SORDS DE BARCELONA (with special thanks to Javi Vidal, who signed the stimuli for the experiment, Santiago Frigola and Delfina Aliaga). We also thank Bencie Woll, Margaret Gillon Dowens, Ansgar Hantsch and the UCSD journal club for their helpful comments on the manuscript. 


\section{REFERENCES}

Amstrong, D. F., Stokoe, W. C., \& Wilcox, S. E. (1995). Gesture and the nature of language. Cambridge, England: Cambridge University Press.

Badecker, W., Miozzo, M., \& Zanuttini, R. (1995). The two-stage model of lexical retrieval: Evidence from a case of anomia with selective preservation of grammatical gender. Cognition, 57, 193-216.

Baus, C., \& Carreiras, M. (submitted). Syllabic effects in Catalan Signed Language (LSC).

Brentari, D. (1998). A prosodic model of sign language phonology. Cambridge, MA: The MIT Press.

Brentari, D. (2006). Effects of language modality on word segmentation: An experimental study of phonological factors in a sign language. In L. Goldstein, W.D. Whalen, C. T. \& Best (Eds.). Papers in Laboratory Phonology 8 (pp.155164). Berlin: Mouton de Gruyter.

Caramazza, A. (1997). How many levels of processing are there in lexical access? Cognitive Neuropsychology, 14(1), 177-208.

Carreiras, M., Gutierrez-Sigut, E., Baquero, S., \& Corina, D. P. (2008). Lexical processing in Spanish Signed Language (LSE). Journal of Memory and Language, 58, 100-122.

Carreiras, M., \& Perea, M. (2004). Naming pseudowords and pictures in Spanish: effects of syllable frequency in speech production. Brain and Language, 90, 393-400.

Chinchor, N. (1978). The syllable in ASL. Paper presented at the MIT Sign Language Symposium. Cambridge, Mass.

Cholin, J., Schiller, N. O., \& Levelt, W. J. L. (2004). The preparation of syllables in 
speech production. Journal of Memory and Language, 50, 47-61.

Cohen J. D., MacWhinney B., Flatt M., and Provost J. (1993). PsyScope: A new graphic interactive environment for designing psychology experiments. Behavioral Research Methods, Instruments, and Computers, 25(2), 257-271.

Corina, D. P. (2000). Some observations regarding paraphasia in American Sign Language. In K. Emmorey \& H. Lane (Eds.). The signs of language revisited: An anthology to honor Ursula Bellugi and Edward Klima, (pp. 493-507). Mahwah, NJ: Lawrence Erlbaum Associates.

Corina, D. P., \& Knapp, H. (2006). Lexical retrieval in American Sign Language production. In L. M. Goldstein, D. H. Whalen, and C.T. Best, (Eds.). Papers in laboratory phonology 8: Varieties of phonological competence (pp. 213-240). Berlin: Mouton de Gruyter.

Corina, D. P., \& Hildebrandt, U. (2002). Psycholinguistic investigations of phonological structure in American Sign Language. In R. P. Meier, K. Cormier, \& D. Quinto-Pozos (Eds.). Modality and Structure in Signed and Spoken Languages, (pp 88-111). Cambridge: Cambridge University Press.

Corina, D. P., \& Sandler, W. (1993). On the nature of phonological structure in sign language. Phonology, 10, 165-170.

Cuxac, C. (2000). Compositionalité sublexicale morphémique/iconique en Langue des Signes Française. Recherches Linguistiques de Vincennes, 29: 55-72.

Dell, G.S., \& O’Seaghdha, P.G. (1992). Stages of lexical access in language production. Cognition, 42, 287-314.

Emmorey, K. (2002). Language, Cognition and the Brain: Insights from sign language research. Mahwah, NJ: Erlbaum. 
Emmorey, K., \& Corina, D. (1990). Lexical recognition in sign language: Effects of phonetic structure and morphology. Perceptual \& Motor Skills, 71, 1227-1252.

Garrett, M. F. (1980). Levels of processing in sentence production. In B. Butterworth (Ed.), Language Production. Vol. 1: Speech and Talk (pp. 177-220). London: Academic Press.

Glaser, W. R., \& Düngelhoff, F. J. (1984). The time course of picture-word interference. Journal of Experimental Psychology: Human Perception and Performance, 10 (5), 640-654.

Glaser, W. R., \& Glaser, M. O. (1989). Context effect in stroop-like word and picture processing. Journal of Experimental Psychology: General, 118 (1), 13-42.

Hildebrandt U., \& Corina D. P. (2002). Phonological Similarity in American Sign Language. Language and Cognitive Processes, 17, 593-612.

Hohenberger, A., Happ, D., \& Leuninger, H. (2002). Modality dependent aspects of signed language production: Evidence from slips of the hands and their repairs in German Sign Language. In R. P. Meier, K. Cormier, \& D. Quinto-Pozos (Eds.), Modality and structure in signed and spoken language (pp.112-142). Cambridge, England: Cambridge University Press.

Jescheniak, J. D., Schriefers, H., \& Hantsch, A. (2003). Utterance format effects phonological priming in the picture-word task: Implications for models of phonological encoding in speech production. Journal of Experimental Psychology: Human Perception and Performance, 29, 441-454.

Johnston, T. (1989). Auslan: The sign language of the Australian Deaf community. Doctoral dissertation, University of Sydney.

Johnston, T., \& Schembri A. (1999). On defining lexeme in a Signed Language. Sign Language and Linguistics, 2.2: 115-185. 
La Heij, W. (1988). Components of Stroop-like interference in picture naming. Memory \& Cognition, 16 (5), 400-410.

Levelt, W. J. M., Roelofs, A., \& Meyer, A. S. (1999). A theory of lexical access in speech production. Behavioral \& Brain Sciences, 22, 1-75.

Levelt, W. J. M., Schriefers, H., Vorberg, D., Meyer, A. S., Pechmann, T., \& Havinga, J. (1991). The time course of lexical access in speech production: A study of picture naming. Psychological Review, 98, 122-142.

Lupker, S. J. (1979). The semantic nature of response competition in the picture-word interference task. Memory and Cognition, 7, 485-495.

Marentette, P. F., \& Mayberry, R. (2000). Principles for an emerging phonological system: a case study of acquisition of early ASL. In C. Chamberlain, J. P. Morford, \& R. Mayberry, (Eds.) Language acquisition by eye (pp. 71-90). Mahwah, NJ: Lawrence Erlbaum Associates.

Mayberry, R. I., \& Fischer, S. D. (1989). Looking through phonological shape to lexical meaning: The bottleneck of non-native sign language processing. Memory and Cognition, 17, 740-754.

Meier, R. P. (2000). Shared motoric factors in the acquisition of sign and speech. In K. Emmorey \& H. Lane (Eds.), The signs of language revisited: An anthology to honor Ursula Bellugi and Edward Klima. (pp. 331-354). Mahwah, NJ: Erlbaum.

Meyer, A. S. (1992). Investigation of phonological encoding through speech error analyses: achievements, limitations, and alternatives. Cognition, 43, 181-211.

Meyer, A. S. (1996). Lexical access in phrase and sentence production: Results from picture-word interference experiments. Journal of Memory and Language, 35, 477-496. 
Meyer, A. S., \& Schriefers, H. (1991). Phonological facilitation in picture-word interference experiments: Effects of stimulus onset asynchrony and types of interfering stimuli. Journal of Experimental Psychology: Learning, Memory, and Cognition, 17, 1146-1160.

Newkirk, D., Klima, E. S., Canady Pedersen, C., \& Bellugi, U. (1980). Linguistic evidence from slips of the hand. In V.A. Fromkin (Ed.), Errors in linguistic performance: Slips of the tongue, ear, pen and hand, (pp. 165-197). New York: Academic Press.

Newman, A. J., Bavelier, D., Corina, D., Jezzard, P., \& Neville, H. J. (2002). A critical period for right hemisphere recruitment in American Sign Language processing. Nature Neuroscience, 5, 76-80.

Newport, E. (1990). Maturational constrains on language learning. Cognitive Science, $14,11-28$.

O’Seaghdha, P. G., \& Marin, J. W. (2000). Phonological competition and cooperation in form-related priming: Sequential and nonsequential processes in word production. Journal of Experimental Psychology: Human Perception and Performance, 26, 57-73.

Perlmutter, D. (1992). Sonority and syllable structure in American Sign Language. Linguistic Inquiry, 23, 407-442.

Ratcliff, R. (1993). Methods for dealing with reaction time outliers. Psychological Bulletin Review, 114, 510-522.

Rayner, K., \& Posnansky, C. J. (1978). Stages of processing in word identification. Journal of Experimental Psychology: General, 107, 64-80. 
Schriefers, H., Meyer, A. S., \& Levelt, W. J. M. (1990). Exploring the time-course of lexical access in production: Picture-word interference studies. Journal of Memory and Language, 29, 86-102.

Sevald, C. A., \& Dell, G. S. (1994). The sequential cuing effect in speech production. Cognition, 53, 91-127.

Snodgrass, J. G., \& Vanderwart, M. (1980). A standarized set of 260 pictures: Norms for name agreement, image agreement, familiarity and visual complexity. Journal of Experimental Psychology: Human Learning and Memory, 6, 174215.

Stokoe, W. (1960). Sign language structure: An outline of the visual communication systems of the American deaf. Studies in Linguistics. Occasional papers 8. Silver Spring, MD: Linstok Press.

Stokoe, W. (1991). Semantic phonology. Sign Language Studies, 71, 107-114.

Sullivan, M. P., \& Riffel, B. (1999). The nature of phonological encoding during spoken language. Language and Cognitive Processes, 11, 15-45.

Thompson, R., Emmorey, K., \& Gollan, T. H. (2005). “Tip of fingers” experiences by deaf signers. Insights into the organization of a sign-based lexicon. Psychological Science, 16 (11), 856-860.

Wheeldon, L. (2003). Inhibitory form priming of spoken word production. Language and Cognitive Processes, 18 (1), 81-109.

Wilbur, R. (1993). Syllables and segments: Hold the movement and move the holds. In G. Coulter (Ed.), Phonetics and phonology, Vol. 3: Current issues in ASL phonology (pp. 135-166). San Diego, CA: Academic Press. 
Appendix $\mathbf{1}^{1}$. Characteristics of the targets and the semantic distractors used in the experiment (English translation in brackets).

\begin{tabular}{|c|c|c|c|c|c|c|c|c|c|c|c|}
\hline TARGET PICTURE & HS & $\begin{array}{l}\text { N. } \\
\text { Hands }\end{array}$ & $\begin{array}{l}\text { Activity } \\
\text { of the } \\
\text { Hand/s }\end{array}$ & MOV & LOC & SEMANTIC DISTRACTOR & HS & $\begin{array}{l}\text { N. } \\
\text { Hands }\end{array}$ & $\begin{array}{l}\text { Activity } \\
\text { of the } \\
\text { Hand/s }\end{array}$ & MOV & LOC \\
\hline CABALLO [horse] & 3 & 2 & A & $\operatorname{arc}$ & head & TORTUGA [turtle] & $\mathrm{B}+\mathrm{th}$ & 2 & $\mathrm{~A}$ & internal & neutral \\
\hline PUERTA [door] & $\mathrm{B}$ & 2 & $\mathrm{~A} / \mathrm{P}$ & $\operatorname{arc}$ & neutral & PARED [wall] & $\mathrm{B}$ & 1 & A & straight & arm \\
\hline PELO [hair] & F flattened & 1 & A & internal & head & DEDO [finger] & 1 & 1 & A & straight & neutral \\
\hline MANZANA[apple] & A & 1 & A & circle & cheek & FRESA [strawberry] & F flattened & 2 & $\mathrm{~A} / \mathrm{P}$ & internal & forehead \\
\hline CAMA [bed] & $\mathrm{IP}+$ th & 2 & A & internal & neutral & ARMARIO [wardrobe] & A & 2 & A & arc & arm \\
\hline PARAGUAS [umbrella] & 5 & 2 & $\mathrm{~A} / \mathrm{P}$ & internal & neutral & CHUBASQUERO [rain coat] & $\mathrm{C}-\mathrm{A}$ & 2 & A & arc & ches \\
\hline CEBOLLA [onion] & A & 1 & A & straight & cheek & BERENJENA [eggplant] & A modified & 1 & A & circle & shoulder \\
\hline PALACIO [palace] & 5 - O flattened & 2 & A & internal & neutral & GRANJA [farm] & 4 & 2 & A & straight & breas \\
\hline TOMATE [tomate] & O flattened & 2 & $\mathrm{~A} / \mathrm{P}$ & internal & backhand & LECHUGA [lettuce] & IP & 2 & A & circle & neutral \\
\hline BUFANDA [scarf] & $\mathrm{B}$ & 1 & A & $\operatorname{arc}$ & neck & GUANTE [globe] & 4 & 2 & $\mathrm{~A} / \mathrm{P}$ & straight & forehand \\
\hline CAMISETA [t-shirt] & $A+$ th & 1 & A & $\operatorname{arc}$ & neck & PANTALÓN [trousers] & A modified & 2 & A & circle & hip \\
\hline CORDERO [lamb] & 1 & 1 & A & internal & neck & JIRAFA [giraffe] & $\mathrm{C}$ & 2 & $\mathrm{~A} / \mathrm{P}$ & straight & neck \\
\hline AUTOBÚS [bus] & $\mathrm{C}$ & 2 & A & straight & neutral & TAXI [taxi] & $\mathrm{H}$ & 2 & $\mathrm{~A} / \mathrm{P}$ & $\operatorname{arc}$ & neutral \\
\hline PERA [pear] & O flattened & 1 & A & $\operatorname{arc}$ & shoulder & LIMÓN [lemon] & 5 curved - S & 1 & $\mathrm{~A}$ & straight & cheek \\
\hline CENICERO [ashtray] & 1 & 2 & $\mathrm{~A} / \mathrm{P}$ & internal & hand & PIPA [pipe] & $\mathrm{Y}$ & 1 & A & no mov. & mouth \\
\hline LAGRIMA [tear] & 1 & 1 & $\mathrm{~A}$ & straight & cheek & PAÑUELO [tissue] & $\mathrm{C}$ & 1 & A & internal & nose \\
\hline MESA [table] & $\mathrm{B}$ & 2 & A & straight & neutral & LAMPARA [lamp] & $S-5$ & 1 & A & straight & head \\
\hline GATO [cat] & 5 curved & 2 & $\mathrm{~A} / \mathrm{P}$ & straight & forearm & CAMELLO [camel] & D flattened & 2 & $\mathrm{~A} / \mathrm{P}$ & internal & head \\
\hline BICICLETA [bicycle] & $\mathrm{Y}$ & 2 & A & circle & neutral & CAMIÓN [truck] & A & 2 & A & straight & nose \\
\hline ESPAGUETI [spaghetti] & I & 1 & A & straight & mouth & COLIFLOR [cauliflower] & 5 curved & 2 & $\mathrm{~A}$ & $\operatorname{arc}$ & ches \\
\hline CHOCOLATE [chocolate] & $\mathrm{H}$ & 2 & $\mathrm{~A} / \mathrm{P}$ & internal & neutral & HELADO [ice cream] & $\mathrm{C}$ & 1 & A & straight & face \\
\hline PINCEL [paintbrush] & G (closed) & 1 & A & zigzag & arm & BOLÍGRAFO [pen] & $A+$ th curved & 1 & A & internal & neutral \\
\hline TREN [train] & A & 2 & $\mathrm{~A} / \mathrm{P}$ & straight & forearm & LANCHA [motorboat] & $\mathrm{B}$ & 2 & A & straight & neutral \\
\hline CAFÉ [coffee] & 8 & 1 & $\mathrm{~A}$ & internal & chin & COCA COLA [coke] & $\mathrm{C}$ & 1 & A & straight & neutral \\
\hline CERDO [pig] & $\mathrm{F}$ & 1 & A & circle & nose & CIERVO [deer] & 1 & 2 & A & internal & heac \\
\hline IGLESIA [church] & O flattened & 1 & A & internal & forehead & CATEDRAL [cathedral] & 5 - O flattened & 2 & A & straight & neutral \\
\hline PERRO [dog] & C flattened & 1 & A & internal & neutral & GALLINA [hen] & 3 & 1 & A & internal & forehead \\
\hline GORRA [cap] & A & 1 & A & $\operatorname{arc}$ & head & CINTURÓN [belt] & A & 1 & A & straight & hip \\
\hline COCHE [car] & $\mathrm{S}$ & 2 & A & internal & neutral & METRO [tube] & $\mathrm{V}$ bent & 2 & $\mathrm{~A} / \mathrm{P}$ & straight & backhand \\
\hline GALLETA [biscuit] & $\mathrm{H}$ & 1 & A & internal & mouth & BOCADILLO [sandwich] & C flattened & 2 & A & straight & neck \\
\hline
\end{tabular}


Characteristics of the targets and the unrelated distractors used in the experiment (English translation in brackets).

\begin{tabular}{|c|c|c|c|c|c|c|c|c|c|c|c|}
\hline TARGET PICTURE & HS. & $\begin{array}{l}\text { N. } \\
\text { Hands }\end{array}$ & $\begin{array}{l}\text { Activity } \\
\text { of the } \\
\text { Hand/s }\end{array}$ & MOV. & LOC. & $\begin{array}{l}\text { UNRELATED } \\
\text { DISTRACTOR }\end{array}$ & HS. & $\begin{array}{l}\text { N. } \\
\text { Hands }\end{array}$ & $\begin{array}{l}\text { Activity } \\
\text { of the } \\
\text { Hand/s }\end{array}$ & MOV. & LOC. \\
\hline CABALLO [horse] & 3 & 2 & $\mathrm{~A}$ & $\operatorname{arc}$ & head & SEPTIEMBRE [September] & F flattened & 2 & $\mathrm{~A} / \mathrm{P}$ & straight & neutral \\
\hline PUERTA [door] & B & 2 & $\mathrm{~A} / \mathrm{P}$ & $\operatorname{arc}$ & neutral & VERANO [summer] & $\mathrm{B}+$ th & 1 & A & straight & forehead \\
\hline PELO [hair] & F flattened & 1 & A & internal & head & GRANADA [pomegranate] & 5 curved & 2 & A & straight & neutral \\
\hline MANZANA[apple] & A & 1 & A & circle & cheek & NEGRO [black] & $\mathrm{V}$ & 1 & A & straight & breast \\
\hline CAMA [bed] & $\mathrm{IP}+$ th & 2 & A & internal & neutral & MADRID [Madrid] & 1 & 1 & A & straight & forehead \\
\hline PARAGUAS [umbrella] & 5 & 2 & $\mathrm{~A} / \mathrm{P}$ & internal & neutral & MAÑANA [morning] & $\mathrm{B}$ & 1 & A & straight & cheek \\
\hline CEBOLLA [onion] & A & 1 & A & straight & cheek & ENVIAR [to send] & 5 flattened & 2 & $\mathrm{~A} / \mathrm{P}$ & internal & neutral \\
\hline PALACIO [palace] & 5 - O flattened & 2 & A & internal & neutral & TARDE [afternoon] & B bent & 1 & A & arc & cheek \\
\hline TOMATE [tomate] & O flattened & 2 & $\mathrm{~A} / \mathrm{P}$ & internal & backhand & ITALIANO [Italian] & IP & 1 & A & $\operatorname{arc}$ & cheek \\
\hline BUFANDA [scarf] & B & 1 & A & arc & neck & POR QUÉ [why] & 1 & 2 & $\mathrm{~A} / \mathrm{P}$ & straight & neutral \\
\hline CAMISETA [t-shirt] & $\mathrm{A}+\mathrm{th}$ & 1 & A & $\operatorname{arc}$ & neck & DIFERENTE [different] & 1 & 2 & $\mathrm{~A} / \mathrm{P}$ & straight & neutral \\
\hline CORDERO [lamb] & 1 & 1 & A & internal & neck & VOLUNTAD [will] & 5 & 2 & A & straight & chest \\
\hline AUTOBÚS [bus] & $\mathrm{C}$ & 2 & A & straight & shoulder & OVIEDO [Oviedo] & $\mathrm{A}+\mathrm{th}$ & 1 & A & $\operatorname{arc}$ & cheek \\
\hline PERA [pear] & O flattened & 1 & A & $\operatorname{arc}$ & shoulder & ENFERMERA [nurse] & 3 - 3 flattened & 2 & A & straight & head \\
\hline CENICERO [ashtray] & 1 & 2 & $\mathrm{~A} / \mathrm{P}$ & internal & hand & CEJA [eyebrow] & C flattened & 2 & $\mathrm{~A}$ & $\operatorname{arc}$ & forehead \\
\hline LAGRIMA [tear] & 1 & 1 & $\mathrm{~A}$ & straight & cheek & ESPERAR [to wait] & A & 2 & $\mathrm{~A} / \mathrm{P}$ & internal & neutral \\
\hline MESA [table] & B & 2 & A & straight & neutral & PREOCUPADO [worried] & O flattened & 1 & A & circle & face \\
\hline GATO [cat] & 5 curved & 2 & $\mathrm{~A} / \mathrm{P}$ & straight & forearm & LOCO [crazy] & 1 & 1 & A & arc & forehead \\
\hline BICICLETA [bicycle] & $\mathrm{Y}$ & 2 & $\mathrm{~A}$ & circle & neutral & AUDÍFONO [hearing aid] & 1 curved & 1 & A & internal & ear \\
\hline ESPAGUETI [spaghetti] & I & 1 & A & straight & mouth & UNIÓN [union] & $\mathrm{F}$ & 2 & A & internal & neutral \\
\hline CHOCOLATE [chocolate] & $\mathrm{H}$ & 2 & $\mathrm{~A} / \mathrm{P}$ & internal & neutral & ROJO [red] & 1 bent & 1 & A & internal & mouth \\
\hline PINCEL [paintbrush] & G (closed) & 1 & A & zigzag & arm & ZARAGOZA [Zaragoza] & A modified & 2 & A & circle & head \\
\hline TREN [train] & A & 2 & $\mathrm{~A} / \mathrm{P}$ & straight & forearm & NOTICIAS [news] & $5-\mathrm{A}$ & 2 & A & circle & neutral \\
\hline CAFÉ [coffee] & 8 & 1 & $\mathrm{~A}$ & internal & chin & PISCINA [swimming pool] & $\mathrm{L}$ & 2 & A & straight & neutral \\
\hline CERDO [pig] & $\mathrm{F}$ & 1 & $\mathrm{~A}$ & circle & nose & ABRIGO [coat] & A & 2 & A & $\operatorname{arc}$ & chest \\
\hline IGLESIA [church] & O flattened & 1 & A & internal & forehead & ESTRELLA [star] & L - L flattened & 2 & A & internal & neutral \\
\hline PERRO [dog] & C flattened & 1 & A & internal & neutral & CÓRDOBA [Cordoba] & bO flattened & 2 & A & $\operatorname{arc}$ & head \\
\hline GORRA [cap] & A & 1 & A & $\operatorname{arc}$ & head & NORMAL [normal] & $\mathrm{F}$ & 2 & A & internal & chest \\
\hline COCHE [car] & $\mathrm{S}$ & 2 & A & internal & neutral & JUBILACIÓN [retirement] & $\mathrm{V}-\mathrm{H}$ & 1 & A & straight & neck \\
\hline GALLETA [biscuit] & $\mathrm{H}$ & 1 & A & internal & mouth & MIERCOLES [Wednesday] & 5 & 2 & A & $\operatorname{arc}$ & neutral \\
\hline
\end{tabular}


Characteristics of the targets and Handshape related distractors used in the experiment (English translation in brackets).

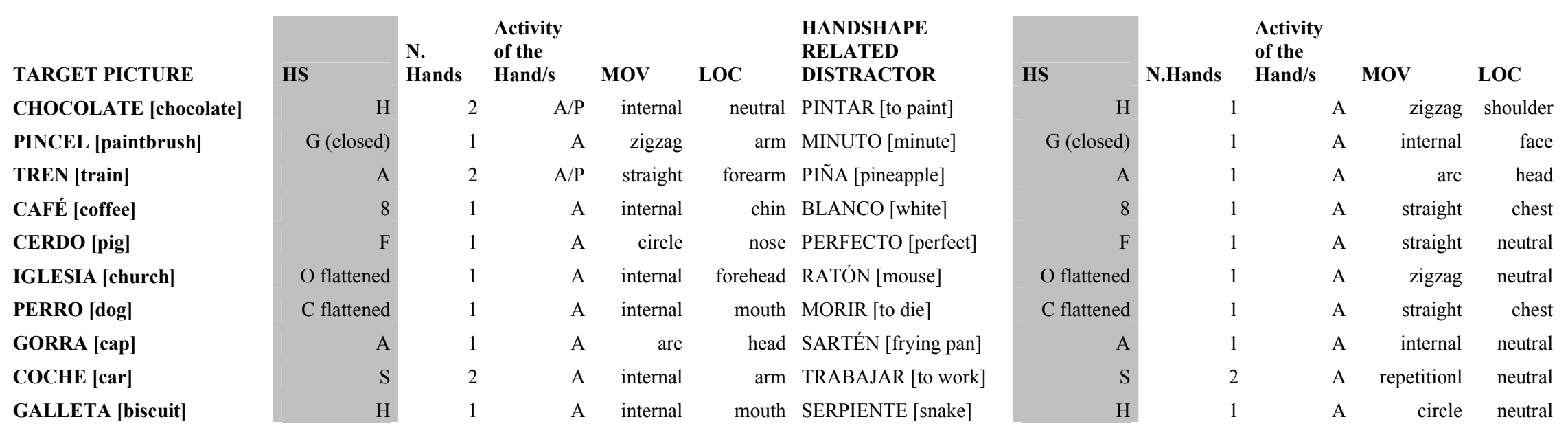


Characteristics of the targets and Movement related distractors used in the experiment (English translation in brackets).

\begin{tabular}{|c|c|c|c|c|c|c|c|c|c|c|c|}
\hline TARGET PICTURE & HS & $\begin{array}{l}\text { N. } \\
\text { Hands }\end{array}$ & $\begin{array}{l}\text { Activity } \\
\text { of the } \\
\text { Hand/s }\end{array}$ & MOV & LOC & $\begin{array}{l}\text { MOVEMENT } \\
\text { RELATED } \\
\text { DISTRACTOR }\end{array}$ & HS & $\begin{array}{l}\text { N. } \\
\text { Hands }\end{array}$ & $\begin{array}{l}\text { Activity } \\
\text { of the } \\
\text { Hand/s }\end{array}$ & MOV & LOC \\
\hline CAMISETA [t-shirt] & $\mathrm{A}+\mathrm{th}$ & & A & arc & neck & NOCHE [night] & $\mathrm{B}$ & 2 & $\mathrm{~A}$ & arc & neutral \\
\hline CORDERO [lamb] & 1 & & A & internal & neck & LLAVE [key] & A modified & 1 & A & internal & neutral \\
\hline AUTOBÚS [bus] & $\mathrm{C}$ & & A & straight & shoulder & REGLA [ruler] & $\mathrm{B}$ & 2 & $\mathrm{~A} / \mathrm{P}$ & straight & arm \\
\hline PERA [pear] & O flattened & & A & $\operatorname{arc}$ & shoulder & RESTAURANTE [restaurant] & $\mathrm{H}$ & 2 & A & $\operatorname{arc}$ & mouth \\
\hline CENICERO [ashtray] & 1 & & $\mathrm{~A} / \mathrm{P}$ & internal & hand & MIEDO [fear] & V curved & 1 & A & internal & chin \\
\hline LAGRIMA [tear] & 1 & & A & straight & cheek & IR [to go] & bO -bO flattened & 1 & A & straight & chest \\
\hline MESA [table] & B & & A & straight & neutral & EXAMEN [exam] & V curved & 1 & A & straight & head \\
\hline GATO [cat] & 5 curved & & $\mathrm{A} / \mathrm{P}$ & straight & forearm & ASCENSOR [lift] & $\mathrm{V}$ bent & 2 & $\mathrm{~A} / \mathrm{P}$ & straight & neutral \\
\hline BICICLETA [bicycle] & $\mathrm{Y}$ & & A & circle & neutral & VIAJAR [to travel] & $\mathrm{L}$ & 2 & A & circle & shoulder \\
\hline ESPAGUETI [spaghetti] & I & & A & straight & mouth & PADRE [father] & $\mathrm{B}$ & 1 & A & straight & forehead \\
\hline
\end{tabular}


Characteristics of the targets and Location related distractors used in the experiment (English translation in brackets).

\begin{tabular}{|c|c|c|c|c|c|c|c|c|c|c|c|}
\hline TARGET PICTURE & HS. & $\begin{array}{l}\text { N. } \\
\text { Hands }\end{array}$ & $\begin{array}{l}\text { Activity } \\
\text { of the } \\
\text { Hand/s }\end{array}$ & MOV. & LOC. & $\begin{array}{l}\text { LOCATION } \\
\text { RELATED } \\
\text { DISTRACTOR }\end{array}$ & HS. & $\begin{array}{l}\text { N. } \\
\text { Hands }\end{array}$ & $\begin{array}{l}\text { Activity } \\
\text { of the } \\
\text { Hand/s }\end{array}$ & MOV. & LOC. \\
\hline CABALLO [horse] & 3 & 2 & A & $\operatorname{arc}$ & head & PENSAR [to think] & O flattened & 1 & A & circle & head \\
\hline PUERTA [door] & B & 2 & $\mathrm{~A} / \mathrm{P}$ & $\operatorname{arc}$ & neutral & NARANJA [orange] & O flattened & 2 & $\mathrm{~A} / \mathrm{P}$ & internal & neutral \\
\hline PELO [hair] & F flattened & 1 & A & internal & head & PIMIENTO [pepper] & 5 flattened & 1 & A & $\operatorname{arc}$ & head \\
\hline MANZANA[apple] & A & 1 & A & circle & cheek & POR FAVOR [please] & $\mathrm{P}+$ th & 1 & A & straight & cheek \\
\hline CAMA [bed] & $\mathrm{IP}+$ th & 2 & A & internal & neutral & HUEVO [egg] & O flattened & 2 & A & internal & neutral \\
\hline PARAGUAS [umbrella] & 5 & 2 & $\mathrm{~A} / \mathrm{P}$ & internal & neutral & FAMILIA [family] & 1 & 2 & A & circle & neutral \\
\hline CEBOLLA [onion] & A & 1 & A & straight & cheek & SECRETO [secret] & A modified & 1 & A & internal & cheek \\
\hline PALACIO [palace] & 5 - O flattened & 2 & A & internal & neutral & PROBLEMA [problem] & $\mathrm{Y}$ & 2 & A & circle & neutral \\
\hline TOMATE [tomate] & O flattened & 2 & $\mathrm{~A} / \mathrm{P}$ & internal & backhand & DE NADA [welcome] & $\mathrm{B}$ & 2 & $\mathrm{~A} / \mathrm{P}$ & straight & backhand \\
\hline BUFANDA [scarf] & B & 1 & A & $\operatorname{arc}$ & neck & SED [thirst] & 1 & 1 & A & straight & neck \\
\hline
\end{tabular}

${ }^{1}$ Note for all the appendices; HS: Handshape; N.Hands: Number of hands participating in the sign; A: Active, A/P: Active/Passive; MOV: Movement; LOC: Location.

Type of Handshapes was extracted from the ASL database of Handshapes. 
Figure 1. Examples of stimuli used in the experiment.

A.
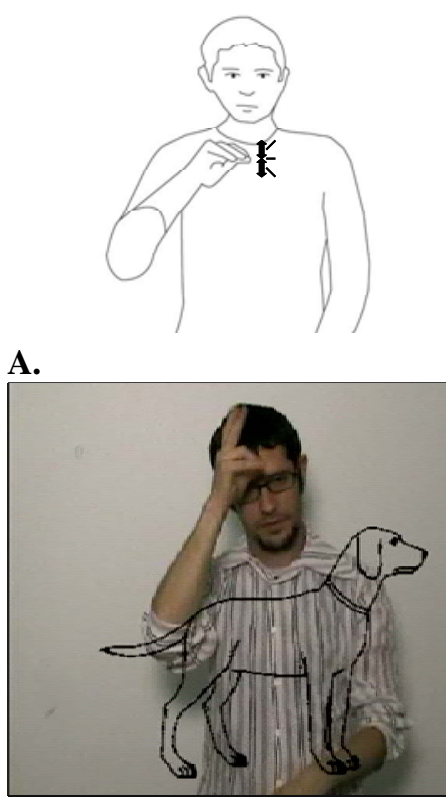

Sign for the target "dog"

B.
C.

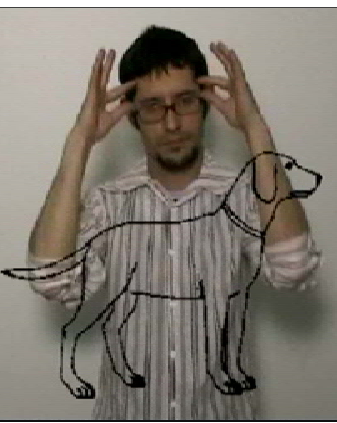

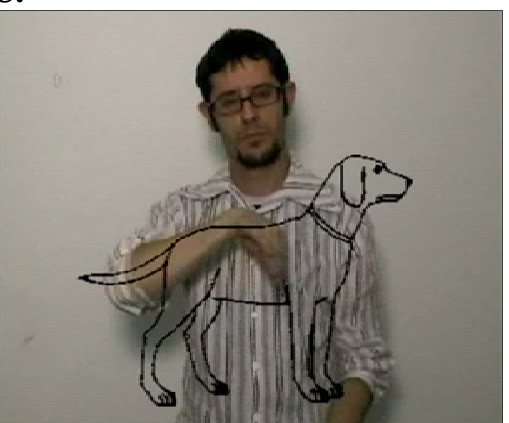

Example of stimuli corresponding to Handshape (picture and sign phonologically related shared the flattened $O$ handshape) condition used in the experiment. A. Example of semantically related condition (PERRO (dog) - gallina (hen)); B. Example of Non-related condition (PERRO (dog) Cordoba (Cordoba is the name of a city in Spain)); C. Example of phonologically related condition (PERRO (dog) - morir (to die).

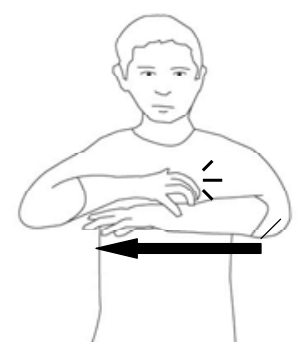

D.

D.

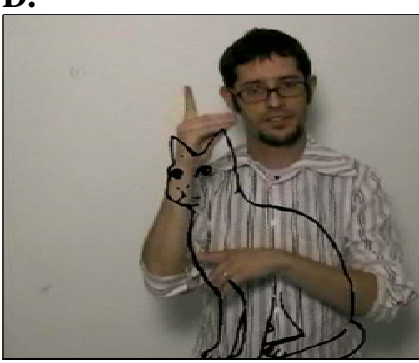

E.

F.

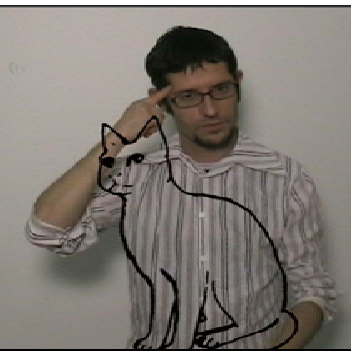

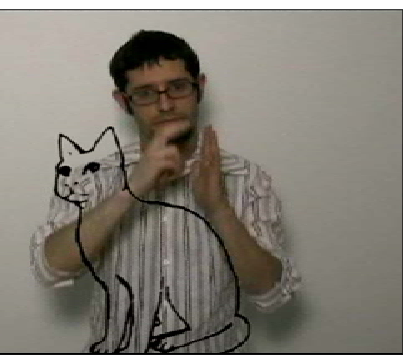

Example of stimuli corresponding to Movement (picture and sign phonologically related share the straight movement) condition used in the experiment. D. Example of semantically related condition (GATO (cat) - camello (camel)); E. Example of Non-related condition (GATO (cat) - loco (crazy)); F. Example of phonologically related condition (GATO (cat) - ascensor (lift)). 
G.

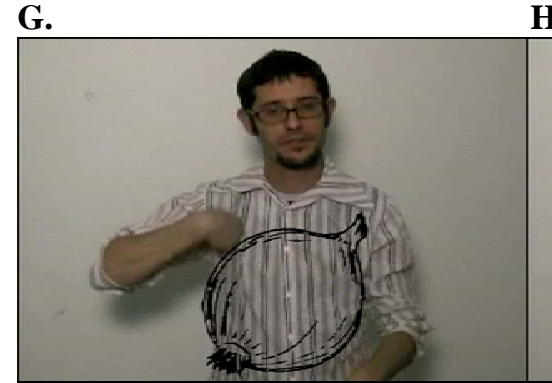

H.

Example of stimuli corresponding to Location (picture and sign phonologically related were located in the right chek) condition used in the experiment. G. Example of semantically related condition (CEBOLLA (onion) - berenjena (eggplant)); H. Example of Non-related condition (CEBOLLA (onion) - enviar (send)); I. Example of phonologically related condition (CEBOLLA (onion) secreto (secret)).

${ }^{1}$ Note: For the pictures representing the targets "dog", "cat" and "onion", the arrow indicates the direction of the movement and the lines indicate the contact with the body. 